\title{
Maximum Rate of Energy Assimilation in the Bank Vole
}

\author{
Katarzyna PIĄTKOWSKA \& January WEINER
}

\begin{abstract}
Piątkowska K. \& Weiner J., 1987: Maximum rate of energy assimilation in the bank vole. Acta theriol., 32, 4: 45-50 [With 1 Fig.]

The maximum cold-induced energy assimilation rate in nonreproducing bank voles Clethrionomys glareolus (Schreber, 1780) was estimated by means of feeding trials. It reached $2.56 \mathrm{~kJ} \times \mathrm{g}^{-1} \times \mathrm{day}^{-1}$, which is only about 3 times the basal metabolic rate, and approaches the level of the average daily energy budget of this species. This is, however, much less than the assimilation rate previously reported for lactating bank voles.

[Department of Animal Ecology, Jagiellonian University, Karasia 6, 30-060 Kraków, Poland].
\end{abstract}

\section{INTRODUCTION}

Energy budgets of free-living mammals are affected by a variety of environmental and physiological factors. Short-term energetical efforts often results in negative energy balances. On the long run, however, the energy expenditure must be balanced by the energy assimilated from food. Thus, the ultimate upper limit to energy budgets of animals is determined by the maximum rate of energy assimilation.

In contrast to the numerous accounts concerning the extreme shortterm energy outputs (e.g. maximum aerobic metabolism, maximum rate of heat production, etc.; see Heldmaier, 1971; Taylor et al., 1981; and Grodziński, 1985; for reviews), not much is known about the long-term upper limit to energy assimilation. Some studies on the energy consumption by large herbivores, which is limited by chemical composition of diet (see Hudson \& White, 1985, for a review), and Kendeigh's (1972) "available productive energy" of sparrows can be interpreted as the measures of longterm upper limit of energy assimilation. More recently Kirkwood (1983) has drawn attention to the importance of this problem. In an attempt to evaluate a general allometric formula scaling the maximum energy assimilation to the body weight, he has gathered diverse data on high metabolisable energy intakes in various homeotherms. None of these data, however, were purposingly measured as the maximum attainable assimilation rate. Within the framework of a 
similar concept, Gross et al. (1985) studied the influence of elevated energy requirements and deteriorated quality of food on gut morphology and maximum dry mass intake in voles.

In this study we attempted to measure directly the highest attainable energy assimilation rate in non-reproducing, small mammalian herbivores. The experimental design consisted in foodbalance trials at various levels of temperature-induced high energy budgets.

\section{MATERIAL AND METHODS}

Bank voles Clethrionomys glareolus (Schreber, 1780) were captured in autumn 1982 in Niepolomice Forest near Kraków The animals weighing on average 19.6 (S.D.=2.2) g were kept at room temperature, natural photoperiod, and fed ad lib. Three days before the experimental trial the voles were put on the homogenized experimental diet, composed of wheat bran, grinded carrots and dehydrated skim milk in weight proportions $4: 3: 3$. This food contained $17.5 \%$ crude protein, $3.5 \%$ fat, and $16.9 \mathrm{~kJ}$ energy per gram dry mass.

The experiments were carried out during winter, but the voles were acclimated to the room temperature. To avoid the effect of a short-term acclimation during experiments, each individual was used only in one trial. The animals $(n=8-11)$ were placed into standard metabolic cages for small mammals (Drożdż, 1975) and into a climatized $( \pm 2 \mathrm{deg})$ chamber. Each experiment lasted for 3 days. Every day the animals were weighed to the nearest $0.1 \mathrm{~g}$. Uneaten food, faeces, and urine were collected at the end of each trial, and subsequently dried, weighed and the samples combusted in an adiabatic bomb calorimeter (Górecki, 1975). Five experimental ambient temperatures were applied: $+20,+10,+5,0$, and $-5^{\circ} \mathrm{C}$. This procedure allowed to estimate energy consumption (C), fecal and urinary energy $(\mathrm{F}, \mathrm{U})$, coefficient of digestibility $((\mathrm{C}-\mathrm{F}) / \mathrm{C})$, and energy assimilation, rate $(\mathrm{A}=\mathrm{C}-(\mathrm{F}+\mathrm{U}))$; (Dróżdż, 1975).

All results are expressed in $\mathrm{kJ}$, averages are given with \pm S.E. Differences between group averages were tested with one-way ANOVA (Sokal \& Rohlf, 1981).

\section{RESULTS AND DISCUSSION}

All animals survived the experiments at temperatures higher than $0^{\circ} \mathrm{C}$. At $0^{\circ}$ and $-5^{\circ} \mathrm{C}$ over $60 \%$ of individuals died during all trials: (the results reported concern only the individuals that survived). The voles maintained a constant body mass only at $10^{\circ} \mathrm{C}$, in all other temperatures their body mass dropped, most distinctly at cold ambients (Fig. 1 a; differences significant at $1 \%$ level). The initial body weights did not differ statistically among experimental groups.

In the range of ambient temperatures from $+5^{\circ} \mathrm{C}$ to $+20^{\circ}$ the energy consumption increases linearly with decreasing temperature (Fig. 1b), reaches a maximum of $3.26 \pm 0.23 \mathrm{~kJ} \times \mathrm{g}^{-1} \times$ day $^{-1}$ at $+5^{\circ} \mathrm{C}$, and drops again at even lower temperatures. A similar pattern of changes is followed by the coefficient of assimilation of food with the peak efficiency of $82.8 \pm 7.2 \%$ (Fig. $1 \mathrm{c}$ ). Consequently, the rate of energy 
assimilation also reaches a distinct maximum at $+5^{\circ} \mathrm{C}(2.56 \pm 0.21 \mathrm{~kJ} \times$ $\times \mathrm{g}^{-1} \times$ day $^{-1}$; Fig. $1 \mathrm{~d}$ ). ANOVA reveals statistically significant differences at $10 \%$ level among assimilation coefficients and on the level of $1 \%$ in all other variables examined.

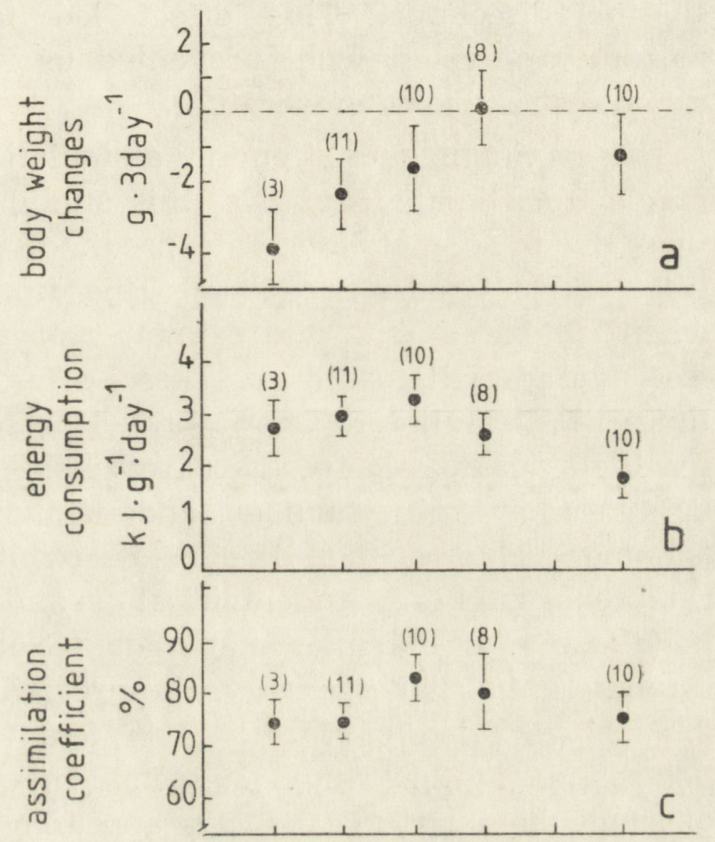

Fig. 1. Changes in the elements of energy balance of the bank voles at various ambient temperatures (averages \pm 2 S.E. and number of observations in parentheses are given). $a$ - body weight changes, $b$ - energy consumption, $c$ coefficient of energy assimilation, $d$ - energy assimilation.

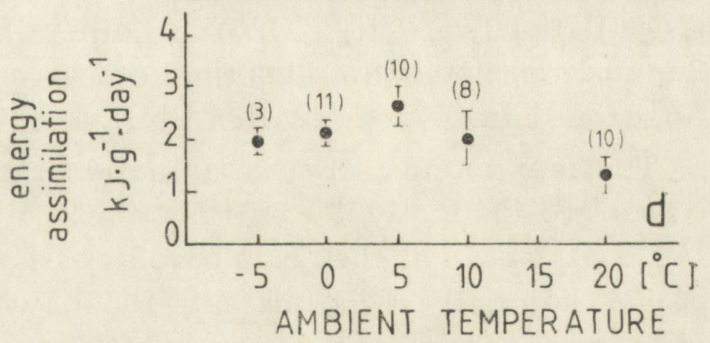

The maximum value of the daily energy assimilation has been reached by the bank voles at $+5^{\circ} \mathrm{C}$. This was achieved not only by the maximized consumption at that temperature, but also by the improved efficiency of food digestion. This last effect has been reported for several species of small mammals (more recently for Clethrionomys by Jensen, 1981). A slight decrease in body mass at the ambient temperature close to thermoneutrum of the bank voles (Grodziński \& Górecki, 1967; Górecki, 1968) may be connected - with adjusting the body mass to the thermal comfort situation. It might have also been caused by some behavioural factors.

All parameters of the energy budget (consumption, assimilation, ef- 
ficiency of digestion) decreased, rather than maintained a plateau at the temperatures lower than that at which maxima have been reached (Fig. 1). This may be explained as an effect of general deterioration of animals' condition at the continuously negative energy balance and/or thermal discomfort. This effect led to the dramatically increased mortality of voles, what prevented us from continuing experiments at the lowest ambient temperature.

The maximum rate of energy assimilation reached by the nonreproducing, non-acclimated animals (this study) is only about 3 times greater than the basal metabolic rate predicted for this species (Górecki, 1968; Hart, 1971; Grodziński, 1985). This finding is particularly interesting when compared with the estimates of the average energy budgets of free-living small mammals. These, after various authors, average 2-4 times BMR (Mullen \& Chew, 1973; Karasov, 1981). Daily energy budgets for Clethrionomys glareolus (Grodziński, 1985) amount to 2.55 and 2.18 $\mathrm{kJ} \times \mathrm{g}^{-1} \times$ day $^{-1}$ in summer and winter, respectively, i.e. are equal (summer value) or just $15 \%$ below (winter) the maximum assimilation rate reported here. An empirical formula predicting the average daily metabolic rate of small mammals (Grodziński \& Wunder, 1975) also estimates the daily energy requirement of a bank vole for about $2.2 \mathrm{~kJ} \times \mathrm{g}^{-1} \times$ day $^{-1}$, scarcely $15 \%$ less than the maximal assimilation determined in this study. It seems, therefore, that the energy budgets of small mammals may always approach the actual upper limit of their assimilation capacity. On the other hand, however, the short-term maxima of metabolic rates (induced by cold or exercise) have been shown to exceed over 5 times the BMR (see Grodziński, 1985, for a review).

The maximum energy assimilation rates of the non-reproducing bank voles are distinctly lower than these attained by the lactating females. At peak lactation the female voles assimilated $35.6-41.5 \mathrm{kcal}$ (i.e. 149 $-174 \mathrm{~kJ}$ ) daily (Kaczmarski, 1966), which is 3 times more than the maximum assimilation rate of the non-reproducing individuals (this study). 'This striking difference most probably can be attributed to the lack of any digestive acclimation in the bank voles studied here. It has been shown that during pregnancy and lactation, as well as in the consequence of cold-induced increase in energy demands, small mammals are capable to adjust the size and structure of their digestive organs (Myrcha, 1964; Gębczyńska \& Gębczyński, 1971; Barnett, 1973; Sibly, 1981; Gross et al., 1985). The difference may also be exaggerated by some differences in experimental procedures. Kaczmarski (1966) has applied a very highly digestible diet, including milk.

On the other hand, it is interesting that the currently achievable maximum energy consumption rates hardly exceed the actual energy 
requirements. A very similar situation has been demonstrated in Djungarian hamsters (Phodopus sungorus) of various reproductive status, that were exposed to low ambient temperatures (Weiner, in press). It seems that the changes in energy assimilation capacity, which require considerable restructuration of the gut, are relatively easy to occur, whereas maintaining the high efficiency of energy assimilation is connected with some adverse effects, e.g. increased metabolic costs of maintenance (Gross et al., 1985; Weiner, in press). The trade-off between the costs of maintaining the improved assimilation capacity vs. the costs of continuous adjustment to the current nutritional demands, within the adaptation strategy of a small mammal, requires further studies.

Acknowledgements: The authors wish to express their sincere gratitude to Prof. G. Heldmaier and Prof. W. Grodziński for helpful comments on the manuscript. The contribution of the junior author was partly supported by the Humboldt Foundation and completed at the Faculty of Biology (Zoology), Philipps University, Marburg (Federal Republic of Germany).

\section{REFERENCES}

1. Barnett S. A., 1973: Maternal process in the cold-adaptation of mice. Biol. Rev., 48: $477-508$.

2. Drożdż A., 1975: Metabolic cages for small rodents. [In: "Methods for ecological bioenergetics". W. Grodziński, R. Z. Klekowski \& A. Duncan, eds.]. IBP Handbook nr. 24: 346-350.

3. Gębczyńska Z. \& Gębczyński M., 1971: Length and weight of the alimentary tract of the root vole. Acta theriol., 16: 359-369.

4. Górecki A., 1968: Metabolic rate and energy budget in the bank vole. Acta theriol., 13: $341-365$.

5. Górecki A., 1975: The adiabatic bomb calorimeter. [In: "Methods for ecological bioenergetics". W. Grodziński, R. Z. Klekowski \& A. Duncan, eds.]. IBP Handbook nr. 24: 275-289. Blackwell Sci Publ., Oxford.

6. Grodziński W., 1985: Ecological energetics of bank voles and wood mice. Symp. Zcol. Soc. Lond., 55: 169-192.

7. Grodziński W., \& Górecki A., 1967: Daily energy budgets of small rodents. [In: "Secondary productivity of terrestrial ecosystems". Ed. K. Petrusewicz]. PWN, Warszawa-Kraków. 295-314.

8. Grodziński W. \& Wunder B., 1975: Ecological energetics of small mammals. [In: "Small mammals: their productivity and population dynamics". F. B. Golley, K. Petrusewicz \& L. Ryszkowski, eds.]. IBP Vol. 5. Cambridge University Press, Cambridge. 173-204.

9. Gross J. E., Wang Z. \& Wunder B. A., 1985: Effect of food quality and energy needs: changes in gut morphology and capacity of Microtus ochrogaster. J. Mammal., 64: 661-667.

10. Hart J. S., 1971: Rodentş. [In: "Comparative physiology of thermoregulation". Ed E. C. Whittow]. Academic Press, New York-London. 2-130.

11. Heldmaier G., 1971: Zitterfreie Wärmebildung und Körpergrösse bei Säugetieren. Z. vergl. Physiol., 73: 222-248.

12. Hudson R. J. \& White R. ., 1985: Bioenergetics of wild herbivores. CRC Press, Inc., Boca Raton. $1-314$. 
13. Jensen T., 1981: Energy flow through Danish forest rodent populations. Natura Jutlandica, 19: 73-80.

14. Kaczmarski F., 1966: Bioenergetics of pregnancy and lactation in the bank vole. Acta theriol., 11: 409-417.

15. Karasov W. H., 1981: Daily energy expenditure and the cost of activity in a free-living mammal. Oecologia, 51: 253-259.

16. Kendeigh S. C., 1972: Monthly variations in the energy budget of house sparrow throughgout the year. [In: "Productivity, population dynamics and systematics of granivorous birds". S. C. Kendeigh \& Pinowski, eds.]. PWN, Warszawa. 17-44.

17. Kirkwood J. K., 1983: A limit to metabolisable energy intake in mammals and birds. Comp. Biochem. Physiol., 75A: 1-3.

18. Mullen, R. K. \& Chew, R. M., 1973: Estimating the energy metabolism of freeliving Perognathus formosus: a comparison of direct and indirect methods. Ecology, 54: 633-637.

19. Myrcha A., 1964: Variations in the length and weight of the alimentary tract of Clethrionomys glareolus (Schreber, 1780). Acta theriol., 9: 139-148.

20. Sibly R. M., 1981: Strategies in digestion and defecation. [In: "Physiological ecology". C. R. Townsend \& P. Calow, eds.] Blackwell Sci. Publ., Oxford.

21. Sokal R. R. \& Rohlf F. J., 1981: Biometry. Freeman \& Co., San Francisco.

22. Taylor C. R., Maloiy G. M. O., Weibel E. R., Langman V. A., Kamau J. M. Z., Seeherman H. J. \& Heglund W. C., 1981: Design of the mammalian respiratory systems. III. Scaling maximum aerobic capacity to body mass; wild and domestic mammals. Resp. Physiol., 44: 25-37.

23. Weiner J., 1987: Maximum energy assimilation rates in the Djungarian hamster (Phodopus sungorus). Oecologia (in press).

Received, June 2, 1986. Accepted, June 11, 1986.

\section{Katarzyna PIĄTKOWSKA i January WEINER}

\section{MAKSYMALNE TEMPO ASYMILACJI ENERGII U NORNICY RUDEJ}

U nornic rudych (Clethrionomys glareolus Schreber, 1780) w okresie zimowym zmierzono konsumpcję i asymilację energii w 5 temperaturach otoczenia: +20 , $+10,+5,0$ i $-5^{\circ} \mathrm{C}$. W temperaturach poniżej $10^{\circ} \mathrm{C}$ zaznaczył się spadek ciężaru ciała (Fig. 1 a). Maksymalny poziom asymilacji energii wynoszący $2.56 \pm 0.21 \mathrm{~kJ} \times$ $\times \mathrm{g}^{-1} \times \mathrm{doba}^{-1}$ nornice osiągnęły $\mathrm{w}$ temperaturze $+5^{\circ} \mathrm{C}$ (Fig. $1 \mathrm{~d}$ ). W niższych temperaturach konsumpcja i asymilacja energii spadały (Fig. 1 b, d), oraz zaznaczyła się zwiększona śmiertelność. Wzrostowi tempa asymilacji energii towarzyszyła poprawa współczynnika asymilacji (Fig. $1 \mathrm{c}$ ).

Maksymalny poziom asymilacji energii osiągnięty przez nornice rude przekraczał zaledwie 3-k otnie ich metabolizm bazalny i był niewiele wyższy niż szacowane dla nich przeciętne zapotrzebowanie bytowe. Poziom ten był około 3-krotnie niższy niż podawane wcześniej tempo asymilacji energii u nornic w czasie laktacji. Wydaje się zatem, iż małe ssaki dysponują tylko niewielkim marginesem zdolności do asymilowania energii z pokarmu powyżej bieżących potrzeb, są natomiast w stanie w znacznym stopniu dostosowywać tę zdolność do aktualnych wymagań pokarmowych. 